\title{
The importance of supervised practice teaching in university study of university students - future teachers of Slovak and foreign languages
}

\section{[Vyznam pedagogickej praxe $\mathrm{v}$ pregradualnej priprave ucitelov slovenskeho jazyka a cudzich jazykov]}

\author{
Mariana Sirotova - Veronika Michvocikova
}

DOI: 10.18355/XL.2019.12.03.17

\begin{abstract}
The submitted article has a theoretical-empirical character. The main aim of this article is to examine the opinions of university students - future teachers of Slovak and foreign languages about supervised practice teaching by the SWOT analysis. The theoretical part of the article focuses on the elucidation of the realization of the supervised practice teaching's essence by university students of Slovak and foreign languages' teaching in the university educational process. There is very important to characterize the objectives, functions, tasks, and the environment of the supervised practice teaching realized by university students - future teachers of Slovak and foreign languages. The empirical part of the submitted contribution is based on the discovery of the surveyed university students - future teachers of Slovak and foreign languages views about the realization of the pedagogical practice by SWOT analysis. The pedagogical practice of higher education teachers of languages is the part of their pre-gradual grounding. Therefore, it is necessary to analyze its importance, its positives, its significance, and also its possible weakness by the view of university students, who are preparing for the languages' teaching profession.
\end{abstract}

Key words: SWOT analysis, supervised practice teaching, the teaching of Slovak and foreign languages, university education, university students

\begin{abstract}
Abstrakt
Predkladaný článok pozostáva $z$ teoretickej a empirickej časti. Teoretická čast' sa zameriava na náčrt stručných charakteristík a vymedzenia podstaty realizácie pedagogickej praxe u vysokoškolských študentov - budúcich učitel'ov slovenského jazyka a cudzích jazykov. Pedagogická prax je považovaná za významný spôsob prípravy budúcich učitel'ov na svoje povolanie. Dôležité je preto charakterizovanie ciel'ov, funkcií, úloh, ako aj prostredia, v rámci ktorého dochádza k uskutočňovaniu pedagogickej praxe u budúcich učitel'ov jazykov. Empirická čast' predkladaného príspevku je založená na zist'ovaní názorov ciel'ovej skupiny vysokoškolských študentov - budúcich učitel'ov slovenského jazyka a cudzích jazykov na realizáciu pedagogickej praxe prostredníctvom SWOT analýzy. Pedagogická prax vysokoškolských učitel'ov učitel'stva jazykov je súčast'ou pre-graduálnej prípravy budúcich učitel'ov jazykov, a preto je potrebné analyzovat' jej význam, prínos, ako aj prípadné nedostatky z pohl'adu jednotlivcov pripravujúcich sa na učitel'ské povolanie. Výsledky získané prostredníctvom SWOT analýzy predstavujú vhodný spôsob získavania zhodnotenia účinnosti a efektívnosti realizácie pedagogickej praxe učitel'stva jazykov z pohl'adu uvedenej skupiny vysokoškolských študentov.
\end{abstract}

Kl'účové slová: pedagogická prax, SWOT analýza, učitel'stvo slovenského jazyka a cudzích jazykov, vysokoškolská edukácia, vysokoškolskí študenti

\section{Úvod}

Súčasné vysokoškolské štúdium vysokoškolských študentov - budúcich pedagógov, ktorí budú po absolvovaní vysokoškolského štúdia vyučovat' nielen slovenský, ale aj cudzie jazyky je zamerané na ich adekvátnu a optimálnu prípravu na učitel'ské 
povolanie. K tomuto ciel’u napomáha predovšetkým vysokoškolská výučba realizovaná prostredníctvom prednášok a seminárov (Song et al., 2017; Masalimova et al., 2017). Okrem toho je však nevyhnutné, aby vysokoškolskí študenti - budúci učitelia slovenského jazyka, ako aj cudzích jazykov postupne nadobúdali okrem teoretických vedomostí a poznatkov získaných na základe absolvovania prednášok, seminárov či cvičení aj praktické skúsenosti determinujúce následné efektívne odovzdávanie vedomostí a poznatkov pri vyučovaní jazykov na strednej škole. Skúsenosti podmieňujúce výkon profesie učitel'a pri vyučovaní jazykov možno získavat' kombináciou, a v neposlednom rade hlavne komplementaritou teoretického základu podstaty realizácie povolania učitel’a s následnou aplikáciou daných poznatkov počas pedagogickej praxe. Pedagogická prax predstavuje efektívny spôsob praktického využitia toho, čo sa budúci učitelia priebežne učia počas participácie na vysokoškolskom edukačnom procese (Khrulyova, Sakhieva, 2017; Cao, Kirilova, Grunis, 2017; Gorbunova, Mokeyeva, 2017). Vysokoškolskí študenti sa tak môžu v rámci svojho vzdelávania oboznámit' s teoretickou podstatou, charakteristikami a špecifikami vyučovania jazykov $\mathrm{v}$ školskom prostredí. Následne je dôležité upozornit' na možnost' zapojenia budúcich učitel'ov do reálneho priebehu procesov výchovy a vzdelávania realizovaných na školách. Jedine osobné zapojenie a individuálna angažovanost' môže upevnit' a prehĺbit' to, čo si vysokoškolskí študenti osvojili prostredníctvom teoretického uchopenia podstaty edukačných procesov existujúceho vzdelávacieho systému $\mathrm{v}$ prostredí školy. $\mathrm{Z}$ tohto dôvodu musíme venovat' zvýšenú pozornost' vymedzeniu a charakteristikám pedagogickej praxe vo vyučovaní jazykov. Rovnako si kladieme otázku, akým spôsobom vnímajú pedagogickú prax vysokoškolskí študenti - budúci učitelia slovenského jazyka a cudzích jazykov, ktorí na nej participujú. Zameraním predkladaného článku sústred'ujeme centrum nášho skúmania $\mathrm{k}$ zist'ovaniu postojov a názorov budúcich učitel'ov slovenského jazyk a cudzích jazykov prostredníctvom SWOT analýzy na pozitívne, ako aj na negatívne aspekty praktického uplatňovania nadobudnutých poznatkov z vysokoškolského štúdia v reálnom prostredí stredných škôl.

\section{Teoretické východiská}

Ak sa chceme podrobnejšie zaoberat' nastolenou problematikou, musíme nezanedbatel'ne približit' definície stanovených kl'účových pojmov. V prvom rade upriamujeme centrum našej pozornosti k charakterizovaniu pedagogickej praxe všeobecným vymedzením. Pedagogickú prax považujeme za nevyhnutnú súčast' štúdia učitel'stva predstavujúcu pre študentov možnost' preverenia svojich vedomostí, ako aj schopností, ktoré nadobudli počas vysokoškolského štúdia v reálnom prostredí strednej školy (Rotreklova, 2013: s. 55) Pedagogickou praxou môžu študenti pripravujúci sa na učitel'ské povolanie v prostredí zvolenej strednej školy aplikovat' svoje nadobudnuté poznatky v praxi. Poukazujeme hlavne na zdôraznenie významu realizácie pedagogickej praxe u budúcich učitel'ov slovenského jazyka a cudzích jazykov, nakol'ko je daným študentom poskytovaná možnost' praktického využitia toho, čo sa naučili počas vysokoškolského štúdia. Vedomosti získavané počas štúdia na vysokej škole pripravujú budúcich učitel'ov na uvedené povolanie. Ich samotná participácia na edukačnom procese prebiehajúcom na strednej škole dokáže najlepšie prehíbit' poznatky spojené s vyučovaním jazykov (vid' tiež Mardakhaev et al., 2018), ktoré si vysokoškolskí študenti - budúci učitelia osvojili vo výchovno-vzdelávacom procese realizovaným na vysokej škole. „Ciel'om pedagogickej praxe je získat' profesijné kompetencie pre výkon učitel'ského povolania prepojením teoretických vedomostí a praktických skúseností v reálnom školskom prostredí počas štúdia na vysokej škole.“ (Boberova, Cechlarova, Orosova, 2017: s. 31) Prax uskutočňovanú budúcimi učitel'mi charakterizujeme ako významný spôsob získavania spôsobilostí a kompetencií potrebných pre vykonávanie učitel'ského povolania. Nezanedbatel'ným

XLinguae, Volume 12, Issue 3, June 2019, ISSN 1337-8384, eISSN 2453-711X 
sa stáva práve nadväznost' poznatkov spojených aj s vyučovaním jazykov získaných počas vysokoškolského výchovno-vzdelávacieho procesu a praktickej realizácie daných poznatkov priamo $\mathrm{v}$ konkrétnych podmienkach vyučovacieho procesu zvolenej strednej školy. Pedagogickú prax zároveň považujeme za odbornú prax. Jej hlavným ciel'om je zdokonal'ovanie odborných pedagogických vedomostí či schopností budúcich učitel'ov (vid' tiež Tazhigulova, 2018). Študenti, ktorí sa pripravujú na učitel'ské povolanie tak získavajú na základe autentických skúseností z praxe kompetencie potrebné pre výkon učitel'ského povolania (Krpalek, Krpalkova Krelova, 2018: 42). Vykonávaním pedagogickej praxe pod odborným dohladom cvičného učitel'a, skúseného pedagóga s niekol'koročnou praxou vyučovania jazykov dochádza $\mathrm{k}$ postupnému prehlbovaniu už nadobudnutých poznatkov. Výkon učitel'ského povolania si vyžaduje híbkovú a komplexnú prípravu nielen po stránke nadobúdania potrebných a nevyhnutných teoretických vedomostí (vid' tiež Soradova, Kralova, 2018).

Za nevyhnutné predpoklady optimálneho a adekvátneho vykonávania profesie učitel'a vyučujúceho slovenský jazyk, ako aj cudzie jazyky, považujeme práve autentické skúsenosti získané počas pedagogickej praxe. Pedagogická prax je vnímaná ako vyvrcholenie učitel'ského štúdia. Študent by mal disponovat' množstvom poznatkov, a zároveň by mal byt' pripravený dané poznatky aplikovat', rozširovat' či kultivovat' (Bludis, Pluckov, Staa, 2004: 48). Štúdium učitel'ských predmetov slovenského jazyka a cudzích jazykov na vysokej škole je koncipované takým spôsobom, aby boli vysokoškolskí študenti prvotne oboznámení s teoretickými predpokladmi dôležitými pre nadobudnutie poznatkov o podstate vykonávania profesie učitel'a. Vedomosti, ktoré vysokoškolskí študenti získavajú počas vysokoškolského štúdia je následne potrebné prehlbovat' aj ich praktickým využívaním. Praktická aplikácia nadobudnutých poznatkov pri vyučovaní jazykov je potrebná z hl'adiska požadovanej prípravy budúcich učitel'ov na svoje povolanie. Pedagogická prax sa taktiež podiel'a na konkretizácii, ako aj na systematizácii vedomostí. Okrem toho poskytuje študentom hlavne pedagogické spôsobilosti pre výkon budúceho učitel'ského povolania (Porubska, 2007: 292). Hovoríme tak nielen o zhromažd’ovaní širokého spektra informácií teoretického charakteru zameraných na získanie vedomostí prepojených s charakteristikami a špecifikami prípravy študentov na povolanie učitel'a. Participáciou na praktickej realizácii toho, čo sa vysokoškolskí študenti budúci učitelia slovenského jazyka a cudzích jazykov naučili v rámci teoretického osvojovania si poznatkov, dochádza k nadobúdaniu, rozvíjaniu, a aj následnému upevňovaniu pedagogických spôsobilostí. V neposlednom rade preto môžeme charakterizovat' pedagogickú prax aj ako praktický tréning obsahujúci prípravu na vyučovanie a na všedný školský deň (Kosova-Tomengova, 2015: 46). Organizáciu bežného vyučovacieho dňa považujeme za významný spôsob názornej ukážky priebehu podstaty uskutočňovania výchovno-vzdelávacích procesov v prostredí školy. Vysokoškolskí študenti - budúci učitelia jazykov sa na určitú dobu stávajú súčast'ou pedagogického kolektívu. „V priebehu riadených pedagogických praxí sa študenti učitel'stva po prvýkrát stávajú na relatívne dlhšiu dobu členmi pedagogického zboru fakultných škôl - a aj ked' pracujú pod odborným vedením cvičných učitel'ov - ich práca sa stáva systematickejšia, zodpovednejšia a samostatnejšia." (Krpalek, Krpalkova Krelova, 2018: 42) Vysokoškolskí študenti sa svojou účastou na pedagogickej praxi postupne začleňujú do interakcií prebiehajúcich v rámci kolektívu pedagógov. Uskutočňovanie praxe vplýva na zvyšovanie samostatnosti a zodpovednosti pri aktivitách spojených s výkonom učitel'ského povolania. Odborný dohl'ad cvičného učitel'a taktiež sprostredkuje vysokoškolskému študentovi obraz fungovania pedagogických aktivít v praxi. Študenti pripravujúci sa na svoje budúce povolanie pracujú na základe svojich nadobudnutých vedomostí, a ich následnej praktickej aplikácie do procesu edukácie za pomoci cvičných učitel'ov systematickejšie, ked’že sa postupne učia využívat' to, čo sa naučili participáciou na 
prednáškach a seminároch vysokoškolského edukačného procesu. Tým, že sú vysokoškolskí študenti - budúci učitelia jazykov začlenení do zboru pedagógov na zvolenej strednej škole, ich pracovné aktivity sa začínajú postupne prejavovat' vyššou mierou samostatnosti a zodpovednosti. Vysokoškoláci preberajú vzory správania sa a konania od učitel'ov vykonávajúcich svoje povolanie už niekol'ko rokov. Cviční učitelia sa v mnohých prípadoch stávajú pre svojich potenciálnych budúcich mladších kolegov vzorom, autoritou a osobou, ktorá by ich mala v prípadnom budúcom profesijnom a kariérnom raste motivovat' a nasmerovat'. V praxi sa však stretávame aj s prípadmi, kedy cviční učitelia nevenujú praxujúcim vysokoškolským študentom dostatočné množstvo priestoru a času. Je pravda, že budúci učitelia sa musia počas priebehu pedagogickej praxe rozhodovat' viac či menej samostatne, a rovnako musia preberat' zodpovednost' za svoje konanie, aktivity a organizáciu vyučovacieho procesu.

Vykonávanie pedagogickej praxe považujeme za neodmyslitel'nú súčast' výchovnovzdelávacieho procesu v mnohých krajinách sveta. Ak sústredíme centrum pozornosti na európsky kontinent, možno hovorit' o nasledujúcich spoločných trendoch pedagogickej praxe (Kosova, 2015: 27-28):

1) Gradačný charakter praktickej prípravy - prax tvorí systém na seba nadväzujúcich praxí s vystupňovanou náročnost'ou pre študentov (praktiká či výcviky pripravujúce študentov na vstup do školy, následne asistenčná činnost' študentov)

2) Orientácia na profesijné kompetencie študenta

3) Orientácia na reflexívny charakter praktickej prípravy - dôraz na sebareflexívne spôsobilosti budúceho učitel’a

4) Význam študentského portfólia - portfólio slúži ako významný prostriedok zaznamenania potrebnej spätnej väzby vykonávania pedagogickej praxe.

5) Úzka spolupráca medzi cvičnou školou a univerzitou.

6) Vyzdvihovanie úlohy cvičného učitel'a.

7) Zvyšovanie významu hodnotenia pedagogickej praxe pri celkovom hodnotení vysokoškolského štúdia.

V prvom rade je nevyhnutné zdôraznit' gradačný charakter pedagogickej praxe. Pedagogická prax prebieha postupne na niekol'kých úrovniach. Každá úroveň sa odlišuje iným stupňom náročnosti. Nesmieme zabúdat' ani na význam zohl'adnenia profesijných kompetencií študenta počas vykonávania praxe. Každý jeden človek je jedinečný a disponuje osobnostnými predpokladmi pre vykonávanie učitel'ského povolania. Následná príprava na pedagogickú prax musí byt' založená hlavne na sebareflexii budúceho učitel'a. Praxujúci vysokoškolák by si mal uvedomovat' svoje osobnostné predispozície, a rovnako by si mal vediet' určit' a vybrat' na základe svojej spôsobilosti učebné štýly, ktoré mu najviac vyhovujú, a ktoré sú podl’a jeho názoru najviac adekvátne na výchovu a vzdelávanie mládeže. Podl'a nášho názoru slúži spomenutému ciel'u predovšetkým študentské portfólio.

Pedagogická prax sa podl'a nášho názoru vyznačuje vyššie načrtnutými nezanedbatel'nými znakmi. Okrem toho považujeme za potrebné poukázat' aj na všeobecné ciele, ktoré môžeme zhrnút' nasledovne (Kontirova a kol. 2011: 8-9):

- ilustrácia pedagogickej a psychologickej teórie,

- praktické uplatnenie teoretických znalostí vo výchovno-vzdelávacej praxi pri vyučovaní alebo mimo neho,

- metodický zácvik pod dohl'adom odborníkov,

- prienik do vyučovacej praxe a vykonávanie samostatných vyučovacích výstupov,

- rozvoj pedagogického myslenia,

- učenie sa konaním, prípadne činnost'ou,

- osvojenie si vyučovacích techník, schopností, návykov, odborných zručností,

XLinguae, Volume 12, Issue 3, June 2019, ISSN 1337-8384, eISSN 2453-711X 
- rozvoj pozitívneho vzt'ahu k učitel'skému povolaniu, ako aj k predmetom profesijnej prípravy,

- poskytovanie spätnej väzby o systéme vzdelávania učitel'ov,

- osvojenie si elementárnych metód vedeckého výskumu.

Pedagogická prax smeruje podla nášho názoru hlavne k prepojeniu teoretických poznatkov a vedomostí s ich praktickou aplikáciou. Rovnako nezanedbatel'ným sa stáva aj význam dohl'adu odborníkov - učitel'ov vyučujúcich jazyky na stredných školách, ktorí na základe svojich skúseností a poznatkov dokážu v prípade potreby pomáhat' praxujúcim vysokoškolským študentom pri organizácii procesu edukácie. Aj týmto spôsobom možno rozvíjat' pedagogické myslenie ubudúcich učitel'ov slovenského jazyka a literatúry. Uvedené skutočnosti sa neodmyslitel’ným spôsobom podiel'ajú na vytváraní osobnostných postojov k učitel'skému povolaniu. V neposlednom rade nesmieme zabudnút' upozornit' na význam sprostredkovania spätnej väzby efektívnosti vzdelávania budúcich učitel'ov. Vysokoškolskí študenti zapojení do vykonávania pedagogickej praxe dokážu následne poskytnút' vysokoškolským pedagógom informácie o praktickom využití nadobudnutých poznatkov $\mathrm{z}$ prednášok a seminárov absolvovaných počas vysokoškolského edukačného procesu.

Taktiež doplńame, že pedagogická prax umožňuje študentovi - praktikantovi (Sirotova, 2010: 80-81):

- implementovat' nadobudnuté teoretické poznatky v konkrétnej realizácii vyučovacieho procesu,

- rozvoj pedagogického myslenia,

- ozrejmenie pedagogickej a psychologickej teórie a teórie vedného odboru príslušného aprobačného predmetu

- rozvoj potrebných a nevyhnutných pedagogických schopností a zručností pod vedením odborného cvičného učitel’a

- učenie sa prostredníctvom aktívnej činnosti a konania v prirodzenom školskom prostredí

- spoznávanie reality školskej praxe, ako aj súvislostí ktoré ju ovplyvňujú

- rozvoj pozitívneho vzt'ahu rovnako k vysokoškolskému štúdiu, ako aj k učitel'skému povolaniu

- získavanie spätnej väzby o svojom doterajšom vzdelávaní

- vytváranie morálnych postojov k žiakom, kolegom, rodičom, a v neposlednom rade aj k celej spoločnosti.

Nezanedbatel'ným prínosom pedagogickej praxe pre študenta učitel'stva jazykov je predovšetkým praktické využitie teoretických poznatkov nadobúdaných počas procesu vysokoškolskej edukácie. Opätovne môžeme zdôraznit' význam získania spätnej väzby o tom, akým spôsobom sú pre vysokoškolského študenta významné, a v praxi uplatnitel'né poznatky nadobudnuté počas vysokoškolských prednášok a seminárov. Okrem toho kladieme dôraz aj na neustále rozvíjanie pedagogického myslenia predstavujúceho základný stavebný pilier vytvárania pozitívneho vzt’ahu k učitel'skému povolaniu. Vykonávanie pedagogickej praxe je síce na jednej strane samostatnou aktivitou vysokoškolských študentov - budúcich učitel'ov, no na strane druhej zároveň prebieha pod odborným dohl'adom cvičných učitel'ov, ktorí disponujú rozsiahlejšími a híbkovejšími skúsenost'ami získanými počas vykonávania učitel'skej profesie. Pod vedením cvičného učitel'a je tak možné rozvíjat' pedagogické schopnosti nezanedbatel'né pre výkon budúceho povolania praxujúceho vysokoškolského študenta. Za rovnako dôležité považujeme aj začlenenie vysokoškolského študenta do prirodzeného prostredia školy. V školskom prostredí je budúci učitel' jazykov $\mathrm{v}$ intenzívnom kontakte $\mathrm{s}$ kolegami, so žiakmi, prípadne s rodičmi žiakov. Na základe tohto kontaktu dochádza k rozvoju postojov a názorov na uvedených jedincov, o ktorých si praxujúci študent vytvára svoje vlastné postoje a názory. 


\section{Empirický prieskum}

Na skúmanie nastolenej problematiky zist’ovania postojov a názorov vysokoškolských študentov - budúcich učitel'ov slovenského jazyka a cudzích jazykov spojených s realizáciou pedagogickej praxe bola využitá SWOT analýza. Analyzovali sme 46 zaznamenaných odpovedí vysokoškolských študentov - budúcich učitel'ov slovenského jazyka a cudzích jazykov. Otázky súvisiace so stanovenou tematikou môžeme $\mathrm{v}$ rámci SWOT analýzy rozdelit' na nasledujúce oblasti. V prvom rade sme sa zamerali na zhodnotenie vonkajších a vnútorných činitel'ov ovplyvňujúcich vykonávanie pedagogickej praxe opýtanými vysokoškolskými študentmi - budúcimi učitel'mi slovenského jazyka a cudzích jazykov. V rámci vnútorných faktorov boli skúmané prednosti a nedostatky pedagogickej praxe pri vyučovaní jazykov. Sústredením centra pozornosti na prednosti môžeme hovorit' o silných stránkach vykonávania pedagogickej praxe zahŕňajúce predovšetkým možnosti a podmienky podporujúce realizáciu pedagogickej praxe. $Z$ tohto dôvodu sme zist'ovali, čo ul'ahčí a zjednoduši vykonávanie pedagogickej praxe vysokoškolským študentom - budúcim učitel'om slovenského jazyka a cudzích jazykov.

$\mathrm{Na}$ druhej strane sme $\mathrm{v}$ rámci SWOT analýzy identifikovali vnútorné faktory determinujúce priebeh pedagogickej praxe pri vyučovaní jazykov. Nezabudli sme ani na prípadný výskyt nedostatkov prostredníctvom pohladu participujúcich vysokoškolských študentov. Zist'ovali sme, čo budúcim učitel'om jazykov komplikuje vykonávanie pedagogickej praxe zaznamenané $\mathrm{v}$ slabých stránkach skúmanej problematiky.

Ked’že SWOT analýza pozostáva nielen $\mathrm{z}$ hl'adania vnútorných faktorov ovplyvňujúcich priebeh skúmaného javu, fenoménu alebo stanovenej problematiky, považovali sme za nevyhnutné zamerat' sa aj na určenie vonkajších faktorov podiel'ajúcich sa na výslednom ponímaní pedagogickej praxe u vysokoškolských študentov - budúcich učitel'ov slovenského jazyka a cudzích jazykov. Preto bolo potrebné stanovit' ako d'alšie prednosti pedagogickej praxe hl'adanie toho, čo opýtaní vysokoškolskí študenti praxovaním na zvolenej strednej škole zlepšia vo vzt’ahu k svojej príprave na povolanie učitel'a jazykov. V neposlednom rade smerovalo centrum našej pozornosti aj k zist'ovaniu vonkajších nedostatkov realizácie pedagogickej praxe. Zamerali sme sa na skúmanie mechanizmov, ktoré majú donucovací charakter na vysokoškolských študentov - budúcich učitel'ov slovenského jazyka a cudzích jazykov pri participácii na praxi $\mathrm{v}$ rámci zvolených stredných škôl. Odpovede opýtaných boli individuálne prehl'adne zaznamenávané do nasledujúcej tabul'ky (Tabul'ka 1).

Tabul'ka 1 SWOT analýza

\begin{tabular}{|l|l|l|}
\hline \multicolumn{3}{|c|}{ SWOT analýza } \\
\hline \multirow{2}{*}{ prednosti } & S - silné stránky & O - príležitosti \\
\cline { 2 - 3 } & & \\
\hline \multirow{2}{*}{ nedostatky } & W - slabé stránky & T - hrozby \\
\cline { 2 - 3 } & & \\
\hline & vnútorné & vonkajšie \\
\hline
\end{tabular}

Analýza získaných údajov

Na základe výsledkov SWOT analýzy zameranej na zistenie postojov a názorov opýtaných vysokoškolských študentov - budúcich učitel'ov slovenského jazyka

XLinguae, Volume 12, Issue 3, June 2019, ISSN 1337-8384, eISSN 2453-711X 
a cudzích jazykov súvisiacich s realizáciou pedagogickej praxe môžeme konštatovat' nasledujúce výsledky. V prvom rade sme sa zamerali na analyzovanie možností a podmienok, ktoré by ul'ahčili realizáciu pedagogickej praxe. Ul'ahčenie vykonávania pedagogickej praxe vo vyučovaní jazykov by malo podl'a zaznamenaných postojov a názorov opýtaných vysokoškolských študentov spočívat' hlavne v tom, aby im boli informácie a oznámenie o pedagogickej praxi poskytované skôr. Dlhšie časové obdobie by vysokoškolským študentom poskytlo možnost' lepšieho výberu cvičných škôl, a taktiež by sa mohli na vykonávanie praxe skôr a v predstihu lepšie a efektívnejšie pripravit'. Rovnako je potrebné upozornit' aj na vnímanie cvičných škôl, a predovšetkým cvičných učitel'ov. Cviční učitelia by mali podl'a vyjadrení opýtaných zmenit' svoj prístup k praxujúcim študentom. Ul'ahčenie realizácie pedagogickej praxe prostredníctvom prístupu cvičného učitel'a by malo spočívat' hlavne v ochote a dostatočnej komunikácii s vysokoškolským študentom. Vykonávanie pedagogickej praxe môže byt' z pohl'adu opýtaných vysokoškolských študentov skomplikované pôsobením niekol'kých skutočností. Prvotne je pre oslovených budúcich učitel'ov slovenského jazyka a cudzích jazykov dôležité, aby sa skôr dozvedeli termín uskutočňovania pedagogickej praxe, a mohli si tak v predstihu a s dôkladnejším premyslením zabezpečit’ vyučovacie hodiny na cvičných školách. Okrem toho je teda d’alšou prekážkou optimálnej realizácie pedagogickej praxe aj prístup cvičných učitel'ov $\mathrm{k}$ praxujúcim vysokoškolským študentom. Cviční učitelia sú podl'a zaznamenaných odpovedí SWOT analýzy v mnohých prípadoch zaneprázdnení, často sa stáva, že sa zúčastňujú v čase pedagogickej praxe exkurzií alebo zostanú práce neschopní. V takýchto prípadoch nedokážu vysokoškolským študentom venovat' potrebné množstvo času, ktoré by si vyžadovali pri svojom prvotnom kontakte $\mathrm{s}$ prostredím cvičnej strednej školy. Budúci učitelia jazykov majú taktiež určité očakávania od vedomostí žiakov v súvislosti s preberaným učivom. Častokrát sa však stáva, že poznatky žiakov tieto očakávania nenaplńajú, ich jazyková úroveň je v porovnaní s očakávaniami, a niekedy aj štandardmi nižšia, a vysokoškolskí študenti musia svoju prípravu na vyučovacie hodiny prispôsobovat' poznatkom a vedomostiam vychovávaných a vzdelávaných osôb.

Realizácia pedagogickej praxe vyučovania jazykov smeruje na základe stanovených teoretických východísk nášho článku k niekol'kým ciel'om. Prostredníctvom výsledkov SWOT analýzy môžeme skonštatovat', že z pohl'adu opýtaných vysokoškolských študentov dominovalo vo väčšine zaznamenaných odpovedí zlepšenie si skúseností, ako aj zručností potrebných pre výkon učitel'ského povolania v budúcnosti. Vysokoškolskí študenti participujúci na pedagogickej praxi postupným pravidelným absolvovaním vyučovacích hodín $\mathrm{v}$ pozícii pedagóga nadobúdajú nevyhnutné skúsenosti, ktoré sú žiaduce pri výkone ich budúceho povolania. Nadobúdaním praktických skúseností povolania učitel'a dochádza k optimálnejšiemu zužitkovaniu nadobudnutých teoretických vedomostí počas absolvovania prednášok a seminárov $\mathrm{v}$ rámci vysokoškolskej edukácie. Taktiež nesmieme zabúdat' ani na eliminovanie prípadných stresových situácii prameniacich zo strachu či obavy z vyučovania požadovaného učiva pred žiakmi.

$\mathrm{Na}$ vytvorenie ucelenej SWOT analýzy problematiky realizácie pedagogickej praxe u vysokoškolských študentov - budúcich učitel’ov slovenského jazyka a cudzích jazykov sme sa zamerali aj na zistenie toho, čo pre oslovených vysokoškolákov pôsobí ako donucovací mechanizmus uskutočňovania pedagogickej praxe. Budúci učitelia jazykov sa svojím čiastočným začlenením do pedagogického zboru oboznamujú vo všeobecnosti $\mathrm{s}$ pozitívami, ako aj s negatívami vykonávania učitel'ského povolania.

Vyhodnotením SWOT analýzy je potrebné zosumarizovat', že skoršie oznámenie termínu realizácie pedagogickej praxe by podl'a zaznamenaných postojov a názorov vysokoškolských študentov zjednodušilo výber cvičných škôl. Intenzívnejšia komunikácia s cvičnými školami by mala smerovat' $\mathrm{k}$ dôkladnejšiemu výberu 
cvičných učitel'ov. Participáciou na pedagogickej praxi získavajú vysokoškolskí študenti nevyhnutné skúsenosti a zručnosti spojené s vyučovaním jazykov, ktoré sú potrebné pre výkon učitel'ského povolania $\mathrm{v}$ budúcnosti. Nadobudnutím týchto skúseností dochádza u praxujúcich vysokoškolských študentov $\mathrm{k}$ postupnému eliminovaniu stresu či obáv z vedenia výchovno-vzdelávacích procesov na strednej škole.

Tabul'ka 2 SWOT analýza pedagogickej praxe

\begin{tabular}{|l|l|l|}
\hline \multicolumn{3}{|c|}{ SWOT analýza pedagogickej praxe } \\
\hline \multirow{3}{*}{ prednosti } & S - silné stránky & O - príležitosti \\
\cline { 2 - 3 } & $\begin{array}{l}\text { - skoršie oznámenie } \\
\text { termínu praxe, } \\
\text {-lepší rozvrh }\end{array}$ & $\begin{array}{l}\text {-nadobudnutie skúseností, } \\
\text { zručností }\end{array}$ \\
\hline \multirow{3}{*}{ nedostatky } & W - slabé stránky & T - hrozby \\
\cline { 2 - 3 } & $\begin{array}{l}\text { - prístup cvičných učitel'ov } \\
\text { - čas }\end{array}$ & $\begin{array}{l}\text { - stres } \\
\text { - potreba vzdelávat' a } \\
\text { vychovávat' }\end{array}$ \\
\hline & vnútorné & vonkajšie \\
\hline
\end{tabular}

\section{Diskusia}

Budúci učitelia slovenského jazyka a cudzích jazykov - vysokoškolskí študenti sú počas svojho vysokoškolského štúdia neustále pripravovaní na vykonávanie učitel'ského povolania v budúcnosti. V prvom rade sú oboznamovaní s teoretickými poznatkami potrebnými pre vytvorenie si základu vedomostí vyučovania jazykov. Ked’že vysokoškolské štúdium učitel'stva jazykov poskytuje vysokoškolským študentom široké spektrum poznatkov, je následne potrebné aj ich praktické prevedenie. Vysokoškolskí študenti - budúci učitelia slovenského jazyka a cudzích jazykov sa tak počas svojho vysokoškolského štúdia stávajú na konkrétny stanovený čas súčast'ou kolektívu svojich potenciálnych budúcich kolegov. Majú možnost' a príležitost' vykonávat' $v$ stanovenom časovom harmonograme povolanie učitel'a jazykov v reálnom prostredí zvolenej strednej školy. Pedagogická prax sa vyznačuje všeobecnými a špecifickými ciel'mi smerujúcimi $\mathrm{k}$ nezanedbatel'nej príprave budúceho učitel'a slovenského jazyka a cudzích jazykov na vykonávanie svojej profesie. Ak by pedagogická prax absentovala vo vysokoškolskej príprave vysokoškolských študentov - budúcich učitel'ov slovenského jazyka a cudzích jazykov na výkon učitel'ského povolania, daní študenti by boli ochudobnení o možnost' stat' sa súčast'ou pedagogického kolektívu na zvolenej strednej škole ešte pred tým, ako sa oficiálne stanú učitel'mi. Členstvo v zbore pedagógov umožňuje vysokoškolským študentom hlbšie preniknút' do poznávania podstaty vytvárania, vedenia a usmerňovania procesov výchovy a vzdelávania, a aj vyučovania jazykov na stredných školách.

Vysokoškolskí študenti učitel'stva slovenského jazyka a cudzích jazykov realizujúci pedagogickú prax majú na jej podstatu či priebeh svoje vlastné postoje a názory. Ich prehladné zosumarizovanie vyjadruje aj predkladaná SWOT analýza. Identifikovali sme hlavné možnosti a podmienky podporujúce vykonávanie pedagogickej praxe u budúcich učitel'ov slovenského jazyka a cudzích jazykov. Vyššia efektivita a účinnost' praktického upevňovania a prehlbovania nadobudnutých poznatkov počas prednášok a seminárov vysokoškolskej edukácie by bola podl'a zaznamenaných odpovedí možná na základe skoršieho upovedomenia študentov o pedagogickej praxi. Vysokoškolskí študenti by tak mali viac priestoru zaujímat' sa o svoju cvičnú školu, ako aj viac príležitostí skontaktovat' sa so svojím cvičným učitel'om. Musíme však poznamenat',

XLinguae, Volume 12, Issue 3, June 2019, ISSN 1337-8384, eISSN 2453-711X 
že podl'a nášho názoru je termín pedagogickej praxe oznámený vysokoškolským študentom v dostatočnom časovom predstihu. Problematickým sa stáva až príchod praxujúceho vysokoškoláka na cvičnú školu, kedy môže dôjst' k vyššie spomínaným problémom. V mnohých prípadoch je cvičný učitel' na strednej škole zaneprázdnený, a nedokáže venovat' praxujúcemu študentovi dostatočne potrebné množstvo pozornosti, akú by si vyžadoval. Rovnako dochádza aj k prípadom, že cvičný učitel' ochorie, prípadne je zapojený do iných aktivít na škole, a čas, ktorý mu zostáva na vysokoškolského študenta je minimalizovaný. Môže sa tak stat', že študent vykonávajúci pedagogickú prax nemusí dostat' spätnú väzbu na svoje aktivity. Práve spätná väzba je pri vyučovaní jazykov dôležitý element pomáhajúci budúcemu učitel'ovi optimálnejšie vykonávanie pedagogickej praxe. V prípade vzniknutých problémov, ako aj $\mathrm{v}$ prípade, že potrebuje poradit' $\mathrm{v}$ rôznych smeroch musí často hl'adat' pomoc u iných príslušníkov pedagogického zboru, ktorí nemusia byt' odborníci na vyučovanie jazykov, a prípadne je nútený poradit' si tak, ako sám najlepšie vie. Práve intenzívnejší kontakt cvičného učitel'a $s$ praxujúcim vysokoškolským študentom by podla zaznamenaných odpovedí a z nich vyplývajúcej SWOT analýzy výrazne zoptimalizoval priebeh pedagogickej praxe. V zaznamenaných odpovediach sme sa stretli aj s požiadavkou vyššej časovej dotácie pre vykonávanie pedagogickej praxe, avšak podl'a nášho názoru nie je v štandardnej dížke vysokoškolského štúdia u budúcich učitel'ov jazykov príliš vel'ký priestor na rozširovanie pedagogickej praxe.

Počas priebehu pedagogickej praxe sa taktiež stáva, že vysokoškolskí študenti budúci učitelia slovenského jazyka a cudzích jazykov prichádzajú na cvičnú školu s množstvom vedomostí a poznatkov. Predpokladajú, že žiaci na stredných školách rovnako disponujú rozsiahlym spektrom poznatkov a určitou úrovňou ovládania vyučovaného cudzieho jazyka. Na tieto svoje predpoklady chcú nadviazat' aj svoje vedenia vyučovacích hodín. V prípadoch, kedy žiaci nespíňajú po vedomostnej stránke očakávanú jazykovú úroveň praxujúceho vysokoškolského študenta, dochádza $\mathrm{k}$ reorganizácii a prispôsobeniu vyučovacej hodiny poznatkom a jazykovej úrovni vychovávaných a vzdelávaných osôb. Budúci učitel' tak musí flexibilne pristupovat' $\mathrm{k}$ svojim plánovaným vyučovacím hodinám. Opätovne musíme zdôraznit', že riešením tohto problému by bola prípadná dlhšia časová dotácia pedagogickej praxe počas vysokoškolského štúdia, ktorá by si však vyžadovala prepracovanie schválených študijných osnov. Budúci učitel' jazykov by tak mal síce dostatočné množstvo času dlhodobejšie prispôsobit' organizáciu svojho cvičného vyučovania vedomostiam a poznatkom žiakov, avšak celkové vysokoškolské štúdium by sa predížilo o dobu vykonávania pedagogickej praxe.

Uskutočňovanie pedagogickej praxe u vysokoškolských študentov - budúcich učitel'ov slovenského jazyka a cudzích jazykov smeruje bez najmenších pochybností predovšetkým $\mathrm{k}$ získavaniu, ako aj k rozvíjaniu zručností a neodmyslitel'ných skúseností nevyhnutných pre vykonávanie profesie učitel'a $\mathrm{v}$ budúcnosti. Nadobudnuté skúsenosti spojené $\mathrm{s}$ prácou učitel'a budú postupne rozvíjat' u vysokoškolských študentov obraz o pozitívnych aj negatívnych stránkach nimi zvoleného povolania. $\mathrm{V}$ neposlednom rade treba zdôraznit', že prípadný stres alebo strach $\mathrm{z}$ vystupovania pred cvičnou triedou bude postupne eliminovaný vd'aka postupujúcemu pravidelnému priebehu cvičných vyučovacích hodín, ktoré bude viest' praxujúci vysokoškolský študent.

\section{Záver}

Štúdium na vysokej škole pripravuje vysokoškolských študentov - budúcich učitel'ov slovenského jazyka a cudzích jazykov postupne na vykonávanie učitel'skej profesie. Pre vysokoškolského študenta pripravujúceho sa na výkon povolania učitel'a jazykov je v prvom rade nevyhnutné oboznámenie sa s teoretickými poznatkami potrebnými pre efektívne plnenie si povinností svojho budúceho povolania. Iba dôkladné a 
hĺbkové štúdium toho, s čím sa vychovávané a vzdelávané osoby oboznamujú počas prednášok, ako aj seminárov, či cvičení doplnené štúdiom odporúčanej literatúry vysokoškolským pedagógom, dokáže čo možno najviac optimálne, ako aj efektívne nasmerovat' vysokoškolských študentov učitel'stva jazykov $k$ osvojeniu si predpokladov nezanedbatel'ných pre praktickú realizáciu nadobudnutých poznatkov. Praktické zúžitkovanie nadobudnutých vedomostí prostredníctvom vysokoškolského edukačného procesu prichádza už počas jeho priebehu. Neoddelitel'nou súčastou edukačného procesu na vysokej škole je pedagogická prax. Pedagogickú prax realizujú vysokoškolskí študenti - budúci učitelia slovenského jazyka a cudzích jazykov na zvolenej strednej škole. V predkladanom článku sme sa v rámci teoretickej časti zamerali na priblíženie a vymedzenie základných charakteristík, špecifík a podstaty pedagogickej praxe. $\mathrm{V}$ empirickej časti článku sme zmapovali postoje a názory oslovených vysokoškolských študentov učitel'stva jazykov na ich participáciu na pedagogickej praxi prostredníctvom SWOT analýzy. Za hlavné prednosti vyjadrené $\mathrm{v}$ silných stránkach realizácie pedagogickej praxe, ktoré by ul'ahčili jej realizáciu možno považovat' najmä skoršie oznámenie termínu a ochotnejší prístup cvičných učitel'ov k praxujúcim vysokoškolským študentom.

Realizáciou pedagogickej praxe nadobudnú praxujúci vysokoškolskí študenti - budúci učitelia slovenského jazyka a cudzích jazykov potrebné a nevyhnutné skúsenosti, ako aj zručnosti dôležité pre vykonávanie učitel'skej profesie v budúcnosti. Nadobúdanie daných zručností a skúsenosti je na základe výsledkov SWOT analýzy u opýtaných vysokoškolákov rovnako výsledkom realizácie pedagogickej praxe, a zároveň aj čiastočne donucovacím mechanizmom jej vykonávania. Okrem toho netreba zabúdat' pri dôvodoch prinútenia participácie na pedagogickej praxi ani na zdôraznenie túžby vychovávat' a vzdelávat' mládež alebo zist'ovanie výhod a nevýhod učitel'skej profesie, prípadne prehĺbenie či eliminovanie motivácie vykonávania povolania učitel’a v budúcnosti.

S vykonávaním pedagogickej praxe sú spojené podl’a postojov a názorov opýtaných vysokoškolských študentov učitel'stva jazykov aj komplikácie spočívajúce v problematickom rozvrhu a s tým spojeným nedostatočným množstvom času potrebným pre prípravu na prax. Za nedostatok realizácie pedagogickej praxe možno podl'a zaznamenaných odpovedí opýtaných vysokoškolákov považovat' aj neochotný prístup či zaneprázdnenost' cvičného učitel'a, ktorý by bolo možné odstránit' hlavne dlhším časovým rozpätím praxovania na zvolenej strednej škole.

Pedagogická prax je neodmyslitel'nou súčast'ou vysokoškolského štúdia vysokoškolských študentov - budúcich učitel'ov slovenského jazyka a cudzích jazykov. Podl'a nášho názoru by bolo vhodné uskutočnit' s vybranými študentmi učitel'stva jazykov híbkové rozhovory a zamerat' sa na dôkladnejšie skúmanie predností, ako aj nedostatkov jej realizácie. Hlavné východiská a predpoklady pre rozšírenie nášho skúmania by mohli predstavovat' základné zistenia predkladanej SWOT analýzy.

Článok bol spracovaný ako jeden z výstupov v rámci riešenia projektu KEGA 015UCM-4/2018 Pedagogická prax vysokoškolských študentov s podporou virtuálnej dimenzie.

\section{Bibliographic references}

BOBEROVA, Z. - CECHLAROVA, K. - OROSOVA, R. 2017. Organizacia pedagogickej praxe ako (nielen) matematicky problem. In Edukacia. Vedeckoodborny casopis. roc 2, c 1, s. 30-38. ISSN 1339-8725

BLUDIS, J. - PLUCKOVA, I. - STAVA, J. 2004. Par vet o pedagogicke praxi. In Pedagogicka praxe v pregradualni príprave ucitelu (Brno, Ceska republika, Februar, 24, 2018). 
CAO, Y. - KIRILOVA, G.I. - GRUNIS, M.L. 2017. Cooperative Research Projects of Master's Students (Education Programs) in the Open Informational Educational Environment. EURASIA Journal of Mathematics, Science and Technology Education, Vol. 13, n 7, 2859-2868. ISSN 13058223, 13058215

KONTIROVA, S. A KOL. 2011. Pedagogicka prax studentov ucitelstva akademickych predmetov. Košice: UPJŠ. ISBN 978-80-7097-904-4.

KOSOVA, B. - TOMENGOVA, A. 2015. Profesijna prakticka priprava buducich ucitelov. Banska Bystrica: Belianum. ISBN 978-80-557-0860-7

KRIZ, E. 2018. Pedagogicka praxe ucitelu praktickeho vyucovani. In Pedagogicka priprava ucitelu praktickeho vyucovani. (Beroun: Ceska republika, NovemberDecember, 30-1, 2018).

KRPALEK, P. - KRPALKOVA KRELOVA, K. 2018. Pedagogicke praxe a specifika pripravy ucitelu odbornych predmetu z hlediska integrace vyuky. In Pedagogicka priprava ucitelu praktickeho vyucovani. (Beroun: Ceska republika, NovemberDecember, 30-1, 2018).

MARKADKHAEV L. V. - EGORYCHEV A. M. - VARLAMOVA E. Y. KOSTIN E. A. Development of linguo-cultural personality of future teachers within the educational environment of higher educational institutions. Novosibirsk State Pedagogical University Bulletin, 2018, vol. 8, no. 4, pp. 204-216. DOI: http://dx.doi.org/10.15293/2226-3365.1804.13

PORUBSKA, G. 2007. Pedagogicka prax ako prostriedok rozvoja ucitelskych kompetecii. In Pedagogicka prax sucasnost a perspektivy. Nitra: UKF. s 289-298. ISBN 978-80-8094-145-1.

ROTREKLOVA, O. 2013. Priprava vysokoskolskeho studenta ucitelstvi na pedagogickou praxi z biologie. In Na pomoc pedagogicke praxi. Z. Bochnícek, Ed. Brno: Masarykova univerzita. 55-58. DOI: 10.5817/CZ.MUNI.M210-6302-2013

ROSTEKOVA, M. 2018. Francuzsko-slovenska spolupraca ako motor internacionalizacie vysokoskolského vzdelavania na Slovensku. In Politicke vedy. Vol. 21, No. 1, 2018. ISSN 1335-2741, pp. 204-211. Available at: http://dx.doi.org/10.24040/politickevedy.2018.21.1.204-211

SIROTOVA, M. 2015. Pedagogicka prax v pregradualnej priprave ucitelov. Trnava: FF UCM. ISBN 978-80-8105-648-2.

MASALIMOVA, A.R. - LEVINA, E.Y. - PLATONOVA, R.I. - YAKUBENKO, K.Yu. - MAMITOVA, N.V. - ARZUMANOVA, L.L. - GREBENNIKOV, V.V. MARCHUK, N.N. 2017. Cognitive Simulation as Integrated Innovative Technology in Teaching of Social and Humanitarian Disciplines. EURASIA Journal of Mathematics, Science and Technology Education, Vol. 13 n. 8, 4915-4928. ISSN 13058223,13058215

SORADOVA D. - KRALOVA Z. - BIROVA J. "Phonics generalizations" in teaching foreign language pronunciation. Novosibirsk State Pedagogical University Bulletin, 2018, vol. 8, no. 4, pp. 46-54. DOI: http://dx.doi.org/10.15293/22263365.1804 .03

SONG, T. - USTIN, P.N. - POPOV, L.M. - MUDARISOV, M.M. 2017. The Educational Technology of Ethical Development for Students. EURASIA Journal of Mathematics, Science and Technology Education, 13(6), 2095-2110. ISSN 13058223, 13058215

TAZHIGULOVA G. O. - ASSANOVA D. N. - UTEUBAYEVA E. A. MEKEZHANOVA A. B. - TLEUZHANOVA G. K. Conditions of English language teaching to prospective biology teachers in Kazakhstan. Novosibirsk State Pedagogical University Bulletin, 2018, vol. 8, no. 6, pp. 23-40. DOI: http://dx.doi.org/10.15293/2226-3365.1806.02

GORBUNOVA, N.V. - MOKEYEVA, E.V. 2017. Innovative Educational Environment of Higher Educational Institution. Man in India, Vol. 97, n. 15, 21-40. ISSN 0025-1569. 
KHRULYOVA A.A. - SAKHIEVA R.G. 2017. Forming of Informational Culture as a Necessary Condition of the Level Raising of Higher Education. Man In India, Vol. 97, n. 15, 211-225. ISSN 0025-1569.

Words: 5005

Characters: 39764 (22,09 standard pages)

doc. Mgr. Mariana Sirotová, PhD.

Mgr. Veronika Michvocíková, PhD.

Ss. Cyril and Method University in Trnava

Faculty of Letters

Department of education

Nám. J Herdu 2

91701 Trnava

Slovakia

mariana.sirotova@ucm.sk

veronika.michvocikova@ucm.sk 